\title{
Raising Teachers' Voice on Achievement in Urban Schools in England: An Introduction
}

\author{
Lori Beckett
}

Published online: 30 October 2014

(C) Springer Science+Business Media New York 2014

\begin{abstract}
There are intense policy pressures on urban schools and teachers working with different cohorts of disadvantaged students to 'raise achievement' and 'close the gap' in England. Known in the academic literature as disadvantage schools, in government policy circles they were formerly labelled 'challenging schools' now 'under-performing schools' or 'socially-deprived schools'. These urban schools are compelled to meet external policy expectations in regards accountability (national benchmarks and floor targets) or face sanctions. This editorial begins with this extant school policy on achievement and describes a schooluniversity partnership initiative in a northern city that brings together teachers, school Heads and assistant Heads with academic partners, currently without system support, to address disadvantaged students' lives, learning needs and schooling experiences. The article then canvasses what has been done over 3 years with this first cohort to engage in teacher research activity informing school improvement oriented to equity and social justice, and introduces their work now made public in this journal. The intention of this special edition is to showcase these teachers' voice, honed by the practical-pedagogical work done against the odds to advocate more realistic policies and practices that are locally sensitive and contextually specific. It is an example of one local struggle.
\end{abstract}

Leeds Beckett University assumed its new name on 22 September, 2014. Given the timing of the work reported in this special collection, this article will use its former name throughout: Leeds Metropolitan University called Leeds Met by students and staff alike.

L. Beckett $(\square)$

Leeds Beckett University, Leeds, UK

e-mail: L.Beckett@Leedsmet.ac.uk 
In every generation, at every stage in the human story there have always been two flames burning: the flame of anger against injustice and the flame of hope that a better world could be built.

Tony Benn (1997).

\section{Introduction}

The teachers, school Heads, assistant Heads and academic partners assembled in this special edition are the first to collectively tell a story about achievement in urban schools in England, or more specifically in a city-wide network of urban schools in the north of England, in the hope that better school policies will be put in place to quell the professional disquiet if not anger about extant school policy. The main source of annoyance is the capture of teachers' attention away from what they consider should be professionally determined practice towards government prescription, standardisation, and performance with a focus on achievement and test-based accountability. This is all coupled with Office for Standards in Education (Ofsted) inspections which come with extreme high pressure on schools and teachers to achieve certain judgement grades, with each marked accordingly. In turn, this determines teachers' classroom practices and skews students' learning towards external Standard Assessment Tests (SATs) and General Certificate of Secondary Education (GCSE) examinations in favour of shoring up the school's results and place on league tables, with a follow-on effect particularly when urban schools do not meet national benchmarks and floor targets. This often results in 'naming and shaming' urban schools, which can be then targeted for closure to become 'forced' academies with private sponsors.

A recent iteration of extant school policy serves to illustrate the point. In the Introduction to a document curiously titled 'Unseen children: access and achievement 20 years on' Evidence report ${ }^{1}$ (Ofsted 2013), Her Majesty's Chief Inspector (HMCI) Sir Michael Wilshaw states his concern is not with material poverty so much as with a poverty of expectations in the home and school given the effects on student underachievement, poor performance, and outcomes as a measure of success and failure. This requires close reading. While Wilshaw readily acknowledges the link between disadvantage and educational achievement and names economic disadvantage, his focus is on the student's background, low family income, and poor educational outcomes. The policy directions are for schools and colleges to counter academic failure through high expectations and relentless actions in order to improve test/exam results tied to national yardsticks. The teachers' work is then held in check by Ofsted inspection criteria, ${ }^{2}$ which is monitored by constant supervision of teachers in classrooms at regular intervals, intermittent mock school inspections, and Ofsted school inspections at least once every 4 years, depending on the previous grade category. This ranges from 'outstanding' to 'inadequate' often requiring 'special measures'. If judged in the worst category, there are sanctions and more frequent school inspections.

\footnotetext{
${ }^{1}$ See http://www.ofsted.gov.uk/resources/unseen-children-access-and-achievement-20-years.

${ }^{2}$ The most recent iteration of Ofsted inspection criteria, effective September, 2012, is achievement, teaching quality, behaviour, leadership and management.
} 
The flame of professional disquiet if not anger is sparked by the overwhelming demands on practitioners in urban schools to meet ever rising national benchmarks and floor targets and improve results while there remains an apparent refusal to consider mitigating circumstances like material poverty. At the same time, it seems no account is taken of other distinctive features of poverty and deprivation, which can be multiple and cumulative, and their effects on teachers' work and disadvantaged students' learning (see Lupton 2006; Thrupp 2009; Smyth and Wrigley 2013). This is made worse by the intimation that improved learning outcomes will only come about as a result of the tight control of teachers' work as some sort of correction to their perceived bad practice (see Ball 1997). The punitive sanctions effectively ignore what, and how much, practitioners in urban schools actually do to ensure sustained improved learning outcomes for students (see Hayes et al. 2005; Munns et al. 2013; Beckett 2015). There is irritation with the individualistic focus of attention on disadvantaged students and their family's social and economic backgrounds, notably parents' low incomes and perceived low expectations. The extant school policy targets individuals, which diverts not only practitioners' attention but also critical consideration of successive governments' responsibilities to develop school and social policies to address injustice and social and educational inequalities (Wilkinson and Pickett 2010; Jones 2011).

A flicker of hope is lit by public pronouncements about research and its role in teaching and teacher education, although there remains debate over the forms this should take. For example, Goldacre's (2013) paper Building Evidence into Education pre-empted the Department for Education's (2013) consultation titled Research Priorities and Questions [for] Teachers and Teaching; Graham's (2013) presentation Evidence-Based Teaching; and the Department for Education (DfE) sponsored and commissioned school-based research, albeit using randomised control trials, called 'Closing the gap: test and learn' (see Brookes 2014). The leading academics commissioned to provide a series of background papers, ${ }^{3}$ which despite very specific work briefs, is suggestive of some intellectual input derived from their research into school policy deliberations. More than anything, hope is fanned by the British Education Research Association-Royal Society's review of research in teaching and teacher education (see BERA-RSA 2014a, b; Sahlberg 2014; Menter 2013). The BERA-RSA (2014a) final report, Research and the Teaching Profession, provided more refined policy directions:

Many of those who engaged with the BERA-RSA Inquiry into Research and Teacher Education share the concern of policymakers of all persuasions about the underachievement of too many learners across the UK's education systems.

They share the aspiration to 'close the gap' in achievement which leaves so many young people, particularly those at the margins of society, with poor life chances. They are also concerned about the pressures that impact on teachers' capacity to be creative, to innovate to inquire.

\footnotetext{
${ }_{3}$ www.ofsted.gov.uk/resources/access-and-achievement-background-papers.
} 
These two influential organisations, which flag research-informed teaching and evidence-based practice, may well influence the development of better school policy especially in view of the 2015 UK elections. There are precedents for this sort of work, ${ }^{4}$ which is why the teachers' story told here is significant. It reports on a school-university partnership way of working initiated 9 years ago in this city in the north of England to encourage practitioner research into the complexities of teaching students disadvantaged by poverty and deprivation with a view towards contextualised school improvement (see Thrupp 1999; Lupton 2004, 2006; Beckett 2012). It began as a pilot study ${ }^{5}$ in an inner-city urban primary school, contextually located in a local area that scores high on the Index of Multiple Deprivation, ${ }^{6}$ where there was very real evidence of differential patterns of student achievement (see Beckett and Wood 2012). This work was extended into a family of schools ${ }^{7}$ and resulted in a showcase of teacher inquiry projects that took into account urban schools' socio-economic circumstances. The partnership proceeded beyond the life of the funded project, without system support, with an equally small team of academic partners prepared to provide practical-intellectual resources for teacher partners to develop as practitioner-researchers. This ultimately fed into a responsive yet purposeful CPD twin-pack ${ }^{8}$ that consisted of non-accredited and accredited segments to support and develop teacher inquiry with a view to research-informed teaching and teacher education. It survived, again without system support, with local urban schools willing to sign up and commit a small CPD budget for 3 years. The first cohort, who became known as Trailblazers, ${ }^{9}$ decided to 'go public' and provided the journal articles for this special collection.

The primary purpose of this editorial is to give voice to these Trailblazers and their academic partners, who co-constructed professional knowledge to learn from each other about improving disadvantaged students' learning outcomes, and who co-developed plans for teacher inquiry projects. In many respects their research activity is only in the very early stages, not least because they had to work against

\footnotetext{
${ }^{4}$ See Sahlberg et al. (2012) Report in Ireland, which highlights the need for teaching and teacher education to be research-driven. Interestingly, Furlong chaired the BERA-RSA Steering Group, which included Munn and spanned the four jurisdictions of the UK (England, Scotland, Wales and Northern Ireland), while Sahlberg delivered the inaugural BERA annual lecture, London, 21 May, 2014.

${ }^{5}$ On recruitment to Leeds Met from Australia in early 2006, Beckett wrote an introductory letter to a school Head with a proposal for a pilot study, which took a cue from initiatives in Australia and New Zealand in order to tailor a project for the English setting (see Connell et al. 1991; Lingard et al. 2003; Hayes et al. 2005; Groundwater-Smith and Kemmis 2005; and Thrupp 1999). The school Head agreed on condition academic partners constructed a long-term, sustained CPD experience for the school staff, which ultimately spanned 2006-2010.

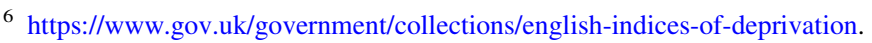

7 This was funded in 2008-2009 by the Teacher Development Agency's 'CPD for schools in challenging circumstances' project.

${ }^{8}$ The two segments, the 'Leading Learning' program and the MA 'Achievement in City Schools' were approved by Carnegie Faculty's Quality and Governance committee at Leeds Met. They are described later in this article.

${ }^{9}$ They were given the title Trailblazers by a former Head of School who had responsibility for Initial Teacher Education (ITE) in the Carnegie Faculty at Leeds Met, given Beckett's proposal to interlink the programmes for student teachers' ITE and practising teachers' continuing professional development (CPD) with Faculty research output.
} 
the odds to engage in professional learning and development, given extant school policy that brought huge pressures to bear, effectively denying any time for professional reading and deliberation much less practitioner research. This special collection has come to fruition only because of their perseverance. The Trailblazers wanted to show the social realities of teachers' work in this network of urban schools in the north of England and what is evidently possible. Their resolve is driven by a concern that teachers, even with the support of their academic partners who bring expert research knowledge and experience to this partnership, can only do so much to meet somewhat unrealistic policy expectations to improve SATs results in Key Stages 1, 2 and 3, and GCSE examination results in urban high schools. These Trailblazers are confronted by incredibly complex demands in this network of urban schools in regards teaching disadvantaged students, often from multi-ethnic and multi-lingual families including immigrants, refugees, and asylum seekers who have also experienced trauma and dislocation. There are also white British students from families who are the traditional working classes, but with deindustrialisation many have experiences of intergenerational unemployment.

\section{Peculiar English Pressures}

From the outset, the Trailblazers and academic partners shared some major professional concerns about the uniformity of policy expectations about 'raising achievement' and 'closing the gap'. Together they came to recognise teachers are pushed towards 'performance pedagogies' identified by Arnot and Reay (2006) in England and/or the 'pedagogies of poverty' described by Haberman (1992) in the USA. They noted the Ofsted inspection criteria, revised over time, does not readily articulate a notion of quality teaching, described in the research literature as 'authentic pedagogy' in the USA (Newmann and Associates 1996) and re-worked as 'productive pedagogies' in Australia (Hayes et al. 2005). They expressed professional disquiet about the intensified policy- and time-pressures, which more often than not provoked the Local Authority to be absent from our workshopsessions ${ }^{10}$ given they are pre-occupied with those urban schools under threat of sanctions. Trailblazers are disturbed by the penalties imposed by this Conservativeled Coalition government, marked by little or no considerations of the contextual circumstances of teachers' work and the effects of poverty and deprivation in their particular localities, which resulted in certain patterns of learning. They can see this couples with the policy conceptualisation of school improvement that refused to recognise "school mix"11 (Thrupp 1999; Lupton 2004, 2006), and that naming and shaming 'failing schools' is strategic, ${ }^{12}$ the result of a particular mix of English

\footnotetext{
${ }^{10}$ The sessions were open to school Heads and their Senior leadership team as well as the Local Authority, who missed all but one of the campus-based sessions. The intention was always to include the officially designated School Improvement partners in the Local Authority, but reduced capacity prevented this happening.

11 Thrupp (1999) refers to the social class composition of a school's intake, but we extend this to consider the student census.

12 This must be seen in relation to 'forced' academies and the privatization agenda.
} 
schools' history, politics, global pressures and local aspirations (Ozga and Lingard 2007).

This English form of vernacular globalisation presented a correspondingly peculiar challenge to academic partners wanting to forge professional learning communities and engage strategies of professional learning that are continuous (see Lieberman and Miller 2008). The 'Leading Learning' CPD segment features a sequence of inter-linked university campus-based and school-based sessions each held once every half-school term over 3 years to support practitioners grow a professional knowledge base. This meant academic partners can provide much needed support in the school but simultaneously not add to the strain of teachers' work in the classroom. In the staged development of the programme, which took a cue from critical reflections on sessions as they happened, academic partners had to find the middle path between the 'policy-oriented' research with 'practice-oriented' research described by Ball (1997) so that policy on achievement was not ignored and theorised 'out of the picture'.

A case in point is the Ofsted inspection criteria, given changes instituted in 2012, the first year of work with this cohort of Trailblazers. The criteria drive school improvement but more frenetically in urban School Development Plans. In a very early campus-based session, a professional learning activity to mobilize teachers' knowledge about what they needed to teach well and to provide insightful explanations indicated the need for evidence about their work in regard each of these Ofsted criteria. This provided a platform for critical discussion of more stringent school inspections. They came to question this tactic as a given part of the solution to improving the learning outcomes of disadvantaged students, and came to recognise school inspection policy is very often part of the problem. Inspectors, which include school management, can ignore teachers' professional judgement about meeting disadvantaged students' learning needs, which are mostly lost in the invariable use of conventional strategies like 'teaching to the test' (Haberman 1992). These Trailblazers and their academic partners are wont to see student learning needs as both academic and social (see Hayes et al. 2005) and engage more responsive curriculum and pedagogical practices. In fact, they all side with Ball (1997) when he questions the problem is 'in' the school or 'in' the teacher but never 'in' policies.

There is certainly some agreement between those of us who attempt to question extant school policy, which is akin to critical policy analysis, and Cochran-Smith et al. (2013) who acknowledged that framing policy in terms of problems and solution is 'not innocent' of values and politics (Bachi 2000 cited by Cochran et al. 2013). This apparent lack of innocence can be seen in contemporary English politicians' and policy-makers' refusals to engage with material poverty and questions about circumstances and social organisation in regards teaching and teacher education. There seems to be an insistence that teaching disadvantaged students marked by poverty and deprivation in urban schools simply requires incessant policy demands for improved results and hounding of teachers, students and their families. The Trailblazers and their academic partners identify with the precept that teaching is much more than training to deliver pre-determined content to be tested and graded. It is a considered intellectual activity that should be research-informed and evidence-based, which requires system support and proper 
resourcing. Another early orientation exercise was to identify and name the complexities in teachers' work with disadvantaged students in urban schools, which of necessity must call into play some nuanced thinking about social markers like poverty, deprivation and social class. They agreed this would entail a detailed interrogation of the meanings of 'closing the gap' and the ways this is inextricably intertwined with social and educational inequalities (see Beckett 2013).

The Trailblazers came to see that likewise they do not stand outside of what Cochran-Smith et al. (2013) call the 'politics of policy'. They came to acknowledge conservatism in the current conjuncture in England is only to be expected, given the larger political and economic conditions, agendas, ideologies and global influences and trends that shape policy identified by Cochran-Smith et al. (2013). These combined discourses and influences, notably neoliberalism and human capital, are one of the four aspects of their idea of the 'politics of policy'. While they articulate the vernacular constructions of the problem, policy in practice, and impact and implementation in the USA, this is played out differently in England. Park's (2013) insights about toxic forms of school accountability and Lingard's (2009) advice that England should be taken as a warning not a system from which to learn are telling. Accordingly, a lack of innocence is quite apparent in the academic partners' own values and educational politics and evident in the CPD twin-pack design and teaching materials (see Beckett 2015), which were well received by Trailblazers.

For me, one of the most striking encounters with a young teacher partner very early in our work together was when she confronted me to ask a question about the date of Mortimore and Whitty's (2000) handbook, Can school improvement overcome the effects of disadvantage?, provided as a reading in the first session. I anticipated a challenge on its age, prepared to answer that this was a seminal text, but I paused to listen to her concern, which framed a question. At the time of publication, she was a school student and now many years later as a teacher in an urban school she was struck by the same problems to do with the persistence of low achievement for students who experience disadvantage and deprivation. Why then, if the profession has the knowledge of the links between achievement and social disadvantage with sensible directions on ways to deal with them, do they remain? I responded with a quip: "It's called the politics of education", but I knew this young teacher's question required an informative answer. A professional and politicised dialogue with teacher partners about research-informed policy and practice to 'raise achievement' and 'close the gap' was built into our CPD twin-pack, which is sensitive to their needs in a performative culture (see Ball 2003, 2013; Ghale and Beckett 2013).

\section{Working at the Chalk-Face}

The 'Leading Learning' segment of the CPD programme was designed to develop a critical perspective on extant school policy and its links to classroom practices, which are mired in what seems to be confusing and contradictory demands on urban schools. Any criticality relied on the need to win the Trailblazers' trust, and academic partners tentatively led by example with an acknowledgement of their own ethical commitments to equity and social justice in order to state a preference 
for a school system that would contribute to more egalitarian English if not global society (see Beckett 2013; Benjamin and Wrigley 2013). In yet another early orientation exercise, they engaged Trailblazers in naming their ethical commitments and values, facilitated by a discussion of some draft principles of procedure to guide this school-university partnership work. They were invited to comment on whether or not they agreed with Kemmis and Robottom's (1989) speculative list. Two are cited here to underline the point. Firstly, that a school's context is complex and important, that it can change over time and that a multitude of variables interact at any one time to impact on practice and efforts to raise achievement. Secondly, it is imperative that any professional discussion about the school and different classroom practices acknowledge a need for negotiation, deliberation and diplomacy, especially when it comes to putting the case on accountability with evidence.

This sort of activity was purposeful because academic partners needed to declare the 'Leading Learning' CPD work was not designed for the evaluation of teachers' work in urban schools but rather concerned to co-develop teacher inquiry projects and contextualized school improvement. It helped shore up Trailblazers' trust, which is hard to come by in a performative culture (see Ball 2003) and laid some crucial foundations to develop their critical perspectives. It too was well received because Trailblazers could see it might be useful when it came to Ofsted inspections given they could share their professional learning and eventually showcase their banks of data/evidence.

To this end, academic partners also had to mentor and support teacher partners to embrace practitioner research, and again this was done by example. They identified with the fact that each school must engage compulsory analyses of the comparative school-national quantitative data delivered in 'Reporting and Analysis for Improvement through School Self-Evaluation' (RAISEonline) as a form of practitioner research. Trailblazers were open to the suggestion to develop a more self-conscious research perspective on the RAISEonline data, especially where it identifies the school context and it is disaggregated by categories such as gender, free school meals, English as an additional language, ethnicity and special educational needs. Trailblazers were keen to take a more critical questioning approach to achievement and any gaps between and among different student groups and to begin to construct their teacher inquiry projects, but these were a long time in the making.

The team of academic partners took RAISEonline as a point of departure to alert Trailblazers to different forms of teacher inquiry to build teacher research knowledge about different cohorts of students identified in disaggregated data (see Tan 2013). Trailblazers were reminded of a long history of practitioner research in England, usually accredited to Stenhouse's (1976) teacher-as-researcher (Leat et al. 2014; Menter et al. 2011) but in actual fact this reaches further back to the pioneers of institution-based teacher training in England following the 1902 Balfour Education Act, notably City of Leeds Training College first Vice-Principal, Winifred Mercier, who as a young teacher had engaged in practitioner research activity at the Manchester Girls High School (see Mercier 1909; Grier 1937; Beckett 2007, 2014). More recently, practitioner research was given some credence by the Strategic Forum for Research in Education (SFRE) review of educational research 
and development ${ }^{13}$ : 'Practitioner enquiry should be an integral, long-term part of provision for professional development and knowledge creation in all educational sectors' (Pollard and Oancea 2010). This preceded the BERA-RSA (2014a, b) Inquiry into research, teaching and teacher education, which no doubt took a cue from Ireland (see Sahlberg et al. 2012). Likewise, the role of teacher inquiry in schools serving disadvantaged students is not without precedent in the USA (Coleman et al. 1966), England (Halsey 1972), and Australia (Karmel 1973).

The Trailblazers' early 'practice' practitioner research, as it came to be called, needed to be lined up with the university's ethics application processes, given the intention of academic partners to co-develop practitioner research investigations. Some components of campus-based sessions were devoted to preparing the different stages of the application, and Trailblazers were also alert to information sheets, consent forms, and draft data collection instruments. Simultaneously, academic partners furnished guidelines on teacher research activity to address the achievement gap from Johnson (2002) and Johnson and La Salle (2010), whose directions to generate 'other' data proved invaluable. For example, in the first year of the 'Leading Learning' segment academic partners encouraged the tabulation of classroom data, including a sample of disadvantaged students' census details with matched data, and classroom observations using the productive pedagogies coding sheet (see QSRLS n.d). Trailblazers also wrote pen portraits of select students, then a student vignette in order to identify professional concerns, triangulated by teacher diary entries. Academic partners presented exemplary samples of Trailblazers' data collection to the cohort, which was invited to engage in collectively developing a critical perspective on research data and classroom practices.

These sorts of exercises have been a central plank to our city-wide researchintensive CPD, geared to exemplify the circumstances and constraints on improving disadvantaged students' learning outcomes. To help Trailblazers indicate their preferences for particular lines of investigation, consecutive university campusbased sessions were devoted to student attendance and behaviour, which are Ofsted markers for school accountability, and an interrogation of truancy research. Trailblazers were invited to draft sample teacher research questions, which was painstaking only because it seemed at odds with the fast pace of urban schools' work and extant school policy directions for short-term quick-fix solutions. However, Trailblazers were amenable to advice about the time needed to learn about constructing teacher inquiry projects, focussing attention on RAISEonline quantitative data, problematising achievement results, engaging critical analyses, and gathering 'other' data in order to develop multiple forms of evidence in support of their claims about mitigating circumstances.

A major frustration for Trailblazers and academic partners locked into England's vernacular 'politics of policy' (see Beckett 2014) was the need to manage some unrealistic policy expectations and incessant time pressures but also find a space for our critical knowledge work together, indicative of the lack of system support. This required academic partners' provision of on-going support in school-based sessions for Trailblazers to identify and name their teacher inquiry focus, triggered by shared

\footnotetext{
13 See www.sfre.ac.uk.
} 
professional concerns about improving learning outcomes in view of disadvantaged student's lives, learning and schooling experiences. Once every half term academic partners met teacher partners in their urban school settings to engage critical discussion of RAISEonline data, co-construct teacher inquiry questions, provide advice on data gathering, engage in practitioner research activities like classroom observations, and meet with school Heads to provide briefings and de-briefings. It was strategic to engage in these conversations with urban school leaders and managers about mixed method practitioner research beyond the Department for Education's commissioned randomised control trials. The school Heads funding Trailblazers in our CPD twin-pack were no doubt alert to their determination to continue this work with academic partners, pool their collective intelligence, and grow a professional knowledge base. This was especially poignant because all the while the teachers' voice is effectively silenced by politicians and policy-makers (see Beckett 2013; Leat et al. 2014; BERA-RSA 2014a, b).

\section{Our On-Going Practical-Pedagogical Work Together}

Coming into the second year Trailblazers were familiar with the arguments for practitioner research in international research literature, for example, CochranSmith and Lytle (2009) on co-developing knowledge-of-practice with academic partners, Groundwater-Smith and Mockler (2007) on quality of evidence, and Sahlberg (2010) on the culture of teaching. In turn this brought home the point about globalisation and other policy-practice configurations beyond the boundaries of the English vernacular approach to extant school policy. Trailblazers could see the worth of comparative analyses and the many different ways to conceptualise and address the challenges of urban schools. One of my teacher partners had already made it known that policy pressures are part of teachers' working life but rather than be constructed as a 'futuristic' teacher who acquiesces to demands she saw merit in being 'a teacher of the future' who engages intellectually (Arthurs 2013, citing Menter 2009). This echoes MacBeath et al. (2007) who noted teachers often find themselves trapped in the force field of turbulent communities and uncompromising government policy. The tension between these two sets of pressures is something to acknowledge (see Lieberman and Miller 2008; Beckett 2015).

By this time, Trailblazers were steadily co-constructing their own teacher inquiry projects, which came to be developed individually, in pairs or in small clusters depending on teachers' locations in their urban schools but always with the support of their academic partner. They were encouraged to take their professional concerns, which had been formulated into draft teacher inquiry questions, and ascertain any potential lines of investigation that could be developed. Again a sequence of university campus-based sessions was devoted to the processes of teacher inquiry, including methods and sample data collection and analyses, including examples like interrogating student work samples (see Beckett 2014; Lingard and Renshaw 2010; Groundwater-Smith 2007; Somekh and Lewin 2007).

Trailblazers continued to find the necessary time for joint meetings on campus but also in school, as well as intellectual activities such as reading and reviewing the 
research literature. Ladson-Billings' (2006) AERA Presidential Address and Milner's (2013) work in the USA proved a significant turning point in developing a more insightful theoretical understanding of 'raising achievement' and 'closing the gap'. The focus then narrowed to social analyses of curriculum (see Anyon 1981; Moll et al. 1992; Dinkins 2009). This critical scholarship was interrogated for substance and structure, for two reasons. Firstly, it helped sharpen Trailblazers' focus on the learning needs of disadvantaged student groups identified in their urban school's disaggregated RAISEonline data. Secondly, it helped develop the terms for their emerging critical social analyses with a view not only to further developing their teacher inquiry projects but feeding back to line managers and the School Leadership teams with recommendations for strategic actions plans, including School Development Plans. By mid-year second year, the majority had signed up to the allied MA 'Achievement in City Schools' and while their assessment tasks were structured to draw on practitioner research activities, these Trailblazers were introduced to more sophisticated theoretical knowledge that gave a depth and breadth to their budding practitioner research.

This dovetailed with a strategic group decision to write up the teacher inquiry projects and 'go public' in journal articles for this special collection, which incidentally entails some professional risk. ${ }^{14}$ It carried into the third year focus of the 'Leading Learning' CPD segment. The sequences of campus-based and schoolbased sessions were scaffolded to hone the teachers' voice, reinforced by the evidence of teacher research activities and the international research literature. Academic partners continued to co-develop an inquiry stance (Cochran-Smith and Lytle 2009) with Trailblazers to take into account contextualised school improvement (Thrupp 1999); exemplary teachers of poverty (Munns et al. 2013); ethnographic research on social class (Cahill 2012); toxic forms of school accountability (Park 2013); and more intelligent forms of school accountability (Lingard 2009). ${ }^{15}$ At each stage, Trailblazers' evaluations of the 'Leading Learning' segment indicated their willingness for on-going work together and their appreciation of developing critical perspectives on extant school policy, teachers' work, curriculum and pedagogical practices in urban schools.

\section{The Teachers' Voice}

It is through the voices of these Trailblazers and academic partners that our practical-pedagogical story of local efforts to 'raise achievement' and 'close the gap' for different and diverse students and groups of students unfolds. Rather than

\footnotetext{
14 They had many conversations with Trailblazers and school Heads about the need for anonymity, which was weighed against the courage of convictions and sanctions in a performative culture.

15 Lingard, Lupton, Cahill and Park each worked with the Trailblazers and academic partners in a 2-h twilight university campus-based session at different times throughout the 3-year 'Leading Learning' CPD segment, while Wrigley took the cohort for the 'MA 'Achievement in City Schools'. Unanimously Trailblazers and academic partners wish to publicly thank these visiting academics. The finale to the 'Leading Learning' CPD segment in November, 2014, was a conference where teacher partners presented their own work to academic partners and Carnegie Faculty Leadership team and teacher education staff.
} 
provide individual introductions to each author, mostly publishing for the first time in this special collection, this editorial provides an opportunity to exemplify the logic of their collective teacher inquiry projects. This effectively maps their professional advice to policy-makers and politicians: accommodate the need for teachers to develop their critical perspectives on the school's achievement data, articulate their professional concerns, and embark on joint investigations with academic partners in order to build the evidence bases, feed research-informed teaching and teacher education, and co-construct school action plans more in line with contextualised school improvement.

Without exception these Trailblazers each share their critical perspectives on extant school policy and its links to classroom practice. This is well exemplified in the first article by Nuttall \& her academic partner Doherty, ${ }^{16}$ who report on a teacher inquiry project that began with an interrogation of the 'official' school data on achievement to develop judicious readings of a sample group of white British boys' disaffection and consequent under-achievement. The teacher partner's investigation was guided by a critical reading of the school's work that not only indicated the sorts of data or evidence to be collected but also enabled her to identify and name the contextual factors that must be taken into account by the school but also by policy-makers and politicians if they are serious about 'raising achievement'.

All the contributors honed their professional concerns about the different rudiments of extant school policy that directed school practice, which were then channelled into draft teacher research questions to guide an articulation of their teacher inquiry project. This is skilfully embodied in the article by Derbyshire, Finn, Griggs and their academic partner Ford, who name twin concerns with the policy directions to train young children at ever younger ages to be school-ready and with official categorisations used by Ofsted, RAISEonline and the Local Authority to describe vulnerable students. These helped frame their interconnected teacher inquiry projects in three urban primary schools, which are works in progress, constructed to take into account the cumulative effects of multiple vulnerabilities and to chart some insightful ways for educationalists to respond.

The teams of teachers and academic partners all co-constructed their investigations alert to the circumstances, constraints and barriers they confront in their efforts to improve the academic and social learning outcomes of students disadvantaged by poverty and deprivation. These are capably identified by Wilson, a teacher partner in a primary school writing a sole-authored article but with support from her academic partner Beckett. Wilson shows how she developed an 'inquiry stance' on quality teaching and some of the impediments that surface in an urban school context, from student disengagement to student ill-health. In an effort to be an exemplary teacher who champions teacher research activity, she harnessed

\footnotetext{
${ }^{16}$ Doherty accompanied Beckett on the first visit to an urban primary school with a proposal to develop the pilot study of a school-university partnership to address student disadvantage. This project work (2006-2010) was the forerunner to the 'Leading Learning' segment of the CPD twin-pack reported here, so it is fitting he features in this special collection. Coincidentally Nuttall and Doherty are both now on staff at Leeds Trinity University.
} 
conceptualisations of quality teaching in two Australian initiatives to develop responsive teaching episodes, which were subjected to critical scrutiny.

The externally imposed directions to urban schools, framed by political agendas, are likewise major considerations for teams of teachers and academic partners wanting to engage in teacher research activity and develop research-informed teaching. This is well considered by Gallagher, an English teacher who is also active in the National Union of Teachers and who is co-authoring with her academic partner Beckett. They share their joint investigation in an urban high school consistently targeted for closure (see Beckett 2012) where the fall-out in terms of reduced student numbers and corresponding financial resources resulted in setting an English class of mixed ability minority ethnic students. This is identified as one major obstruction to addressing their complex learning needs.

The findings that were generated are incisive and insightful, and provide evidence that can be triangulated. A good example is provided by teacher partners Arthurs, Bentley and Patterson, who were located in another one of the urban high schools forced to close and become a sponsored academy before their transfers. With support from academic partners Beckett and Wrigley, they homed in on the attendance-achievement link and provided sound evidence for a more enlightened alternative to the punitive approach to persistent absentees. Another good example of findings is provided by teacher partners Firth, Melia, Bergan and Whitby in yet another urban high school judged to be inadequate against Ofsted measures of achievement but who, with the support of Beckett and Wrigley, developed schoolgenerated evidence to move towards exemplary classroom practice.

In any practitioner research, the data analyses feeding into conclusions and recommendations on school improvement are paramount given reports to school Heads and School Leadership teams. This is the case for urban primary school Head Gorton and urban high school Head Williams, who have each sponsored staff to sign up for the CPD twin-pack, learn the processes of teacher inquiry, and report back to the whole staff. Gorton and Williams co-author, and with support from academic partner Wrigley, ${ }^{17}$ they critically consider the worth of research-active teachers' school-generated evidence and use this in reply to the official judgements that would render urban schools inadequate or worse 'failing schools'.

Harridge and Stokoe with their academic partner $\operatorname{Tan}^{18}$ opted for an idiosyncratic approach to reporting their joint work in an urban primary school, constructed as a conversation piece intended to be a representation of the developmental learning journey and the professional dialogue between research-active teachers and their academic partner. The co-authors and the school Head are certain this captures how they talked in meetings, how the ideas took root, and how questions were posed. In this sense, the narrative is said to be indicative of a continuous analysis. Throughout the development of our school-university partnership work we have always called

\footnotetext{
17 Wrigley is Visiting Professor at Leeds Met, and took a lead role to develop the allied MA 'Achievement in City Schools' in the CPD-twin pack.

18 Tan followed Doherty after his transfer to work with Beckett in this urban primary school, the first to host our initial pilot study (2006-2010), and remained as academic partner when two teachers signed up to the CPD twin-pack (2012-2014). This article is included in this special collection as an acknowledgement of their contribution.
} 
on Lupton $(2004,2006)$ as a consultant academic partner and it is likewise fitting that the final article in this special collection is her response to our work.

\section{Conclusion: A Local Struggle}

These Trailblazers and academic partners along with school Heads and critical friends are willing to engage a professional and politicized dialogue about what it is like to be teaching in urban schools in a performative culture in the north of England. They work in conditions marked by huge policy- and time pressures alongside the imminent threat of punitive school inspections. They are prepared to share the details of their local struggle to provide more equitable and socially just schooling for students and families who experience disadvantage, sometimes in dire circumstances. They work consistently in school and university settings to deeply understand vulnerable students' lives, learning needs and schooling experiences often marked by volatility. They know from their critical reviews of international research literature about what needs to be done to improve academic and social learning outcomes of students disadvantaged by poverty and deprivation, among other things. They are keen to become research-active teachers and generate schoolbased evidence to argue the case for mitigating circumstances, but also to develop research-informed teaching and teacher education.

It has been my privilege to work with these contributors, and I trust readers will find their reports instructive. It must be said that this is a unique special collection of journal articles that foregrounds the teachers' voice with a very clear message about the need to amend extant school policy. However, while I should acknowledge a peer's criticism there is a risk of too much repetition across the journal articles in regards the general points, to the point where it seems labored, they have done well under the circumstances to share what they have learned as nascent research-active teachers. When all is said and done, these Trailblazers and their academic partners personify the flame of disquiet and sometimes anger with being on the receiving end of Conservative policy dictates that seemingly ignore the professional needs of teachers at the chalk-face. For them to develop and provide reports on more complete teacher inquiry projects they need the necessary time to engage in professional deliberations and to plan and execute their investigations. They are more than capable and their intentions are fanned by the roaring flame of hope that the situation will be different after the 2015 UK elections.

\section{References}

Anyon, J. (1981). Social class and school knowledge. Curriculum Inquiry, 11(1, Spring), 3-42.

Arnot, M., \& Reay, D. (2006). The Framing of Performance Pedagogies: Pupil Perspectives on the Control of School Knowledge and Its Acquisition. In H. Lauder, P. Brown, J. Dillabough, \& A. H. Halsey (Eds.), Education, globalisation and social change (Chapter 53) (pp. 654-672). Oxford: Oxford University Press.

Arthurs, N. (2013). Stop! Cloning teachers as Stepford Wives. In L. Beckett (Ed.), Teacher education through active engagement: Raising the professional voice (Chapter 12). London: Routledge Research in Education Policy and Politics Series. 
Ball, S. (1997). Policy Sociology and Critical Social Research: A personal view of recent education policy and policy research. British Education Research Journal, 23(3), 257-274.

Ball, S. (2003). The teacher's soul and the terrors of performativity. Journal of Education Policy, 18(2), $215-228$.

Ball, S. (2013). Policy paper. Education, justice and democracy: The struggle over ignorance and opportunity. London: Centre for Labour and Social Studies, October. http://classonline.org.uk/docs/ 2013_Policy_Paper_-Education,_justice_and_democracy_(Stephen_Ball).pdf.

Beckett, L. (2007). City of Leeds training college: Continuity and change 1907-2007. Leeds: Leeds Metropolitan University.

Beckett, L. (2012). 'Trust the Teachers, Mother!': The leading learning project in Leeds. Improving Schools, 15(1), 10-22.

Beckett, L. (2013). Giving teachers voice-Getting school democracy! National Union of Teachers Education Review, summer 2013.

Beckett, L. (2014). Research-active teachers. 2nd keynote address presented at the British Educational Research Association (BERA)—National College of Teaching and Learning (NCTL). Supporting teachers as researchers conference, Manchester, 30 June.

Beckett, L. (2015). Teachers and Academic Partners Walking the Fault-lines of Professional Practice. London: Routledge.

Beckett, L., \& Wood, J. (2012). Talking honestly in a challenging primary school: England. In T. Wrigley, P. Thompson, \& B. Lingard (Eds.), Changing Schools: Making a world of difference (Chapter 12). London: Routledge.

Benjamin, S., \& Wrigley, T. (2013). The struggle for social justice: A focus on students in poverty. In L. Beckett (Ed.), Teacher education through active engagement: Raising the professional voice (Chapter 11). London: Routledge Research in Education Policy and Politics Series.

British Educational Research Association (BERA)—Royal Society Action and Research Centre (RSA) (2014a). The role of research in teacher education: Reviewing the evidence interim report, London. http://www.bera.ac.uk/wp-content/uploads/2014/02/BERA-RSA-Interim-Report.pdf.

British Educational Research Association (BERA)—Royal Society Action and Research Centre (RSA) (2014b). Research and the teaching profession. Building the capacity for a self-improving education system. Final report of the BERA-RSA inquiry. http://www.bera.ac.uk/wp-content/uploads/2013/12/ BERA-RSA-Research-Teaching-Profession-FULL-REPORT-for-web.pdf.

Brookes, J. (2014). Closing the gap: Test and learn. Presentation to the University Council for the Education of Teachers (UCET) Research and International Committee, London, 27 May.

Cahill, K. (2012). What class are you in? A critical ethnography of school choice, social class and student identity in an urban post-primary school; ethnographic research on social class. Unpublished $\mathrm{PhD}$ research, University College Cork.

Cochran-Smith, M., \& Lytle, S. (2009). Inquiry as stance: Practitioner research in the next generation. New York: Teachers College Press.

Cochran-Smith, M., Piazza, P., \& Power, C. (2013). The Politics of Accountability: Assessing Teacher Education in the United States. The Educational Forum, 77(1), 6-27.

Coleman, J., Campbell, B., Hobson, C., McPartland, J., Mood, A., Winefield, F., et al. (1966). Equality of educational opportunity report. Washington, DC: US Government Printing Office. http://files.eric. ed.gov/fulltext/ED015157.pdf.

Connell, R. W., White, V., \& Johnston, K. M. (1991). 'Running twice as hard'. The Disadvantaged Schools Program in Australia. Geelong: Deakin University Press.

Department for Education. (2013). Research priorities and questions [for] teachers and teaching. Consultation paper, London.

Dinkins, D. (2009). Teachers talk about race, class and achievement. In M. Cochran-Smith \& S. Lytle (Eds.), Inquiry as Stance. Practitioner research for the next generation (Chapter 9). New York: Teachers College Press.

Ghale, B., \& Beckett, L. (2013). Teachers' politicisation. In L. Beckett (Ed.), Teacher education through active engagement: Raising the professional voice (Chapter 13). London: Routledge Research in Education Policy and Politics Series.

Goldacre, B. (2013). Building evidence into education. Paper commissioned by the Department for Education, London. http://dera.ioe.ac.uk/17530/1/ben\%20goldacre\%20paper.pdf.

Graham, K. (2013). Evidence-based teaching. Paper presentation in spotlight session. Department for Education (DfE) Government Approaches to Evidence in Education at British Educational Research Association (BERA) Annual Conference, Brighton. 
Grier, L. (1937). The life of Winifred Mercier. Oxford: Oxford University Press.

Groundwater-Smith, S. (2007). Lesson study as formative assessment in secondary schools. In T. Loughland (Ed.), Proceedings of the authentic assessment practices for student learning conference (pp. 5-18). Sydney: The University of Sydney. http://sydney.edu.au/education_social_work/ professional_learning/resources/2007_papers.shtml.

Groundwater-Smith, S., \& Kemmis, S. (2005). Knowing makes the difference: Learnings from the NSW Priority Action Schools Program. Sydney: NSW Department of Education and Training.

Groundwater-Smith, S., \& Mockler, N. (2007). Ethics in practitioner research: An issue of quality. Research Papers in Education, 22(2), 199-211. http://www.tandfonline.com/doi/abs/10.1080/ 02671520701296171\#.U7v4yZRdWSo.

Haberman, M. (1992, December). The pedagogy of poverty versus good teaching. Phi Delta Kappan. https://www.ithaca.edu/compass/pdf/pedagogy.pdf.

Halsey, A. (1972). Educational priority. EPA problems and policies. Volume 1. Report of a research project sponsored by the Department of Education and Science and the Social Science Research Council. London: HMSO.

Hayes, D., Mills, M., Christie, P., \& Lingard, B. (2005). Teachers and schooling making a difference. Productive pedagogies, assessment and performance. Sydney: Allen and Unwin.

Johnson, R. S. (2002). Using data to close the achievement gap. How to measure equity in our schools. Thousand Oaks, CA: Corwin Press.

Johnson, R. S., \& La Salle, R. A. (2010). Data strategies to uncover and eliminate hidden inequities. The wallpaper effect. Thousand Oaks, CA: Corwin Press.

Jones, O. (2011). CHAVS. The demonization of the working class. London: Verso.

Karmel, P. (1973). Schools in Australia. Report of the Interim Committee for the Australian Schools Commission. Canberra: Australian Government Publishing Service.

Kemmis, S., \& Robottom, I. (1989). Principals of procedure in curriculum evaluation. In ECS801 curriculum evaluation monograph. Geelong: Deakin University.

Ladson-Billings, G. (2006). From the achievement gap to the education debt: Understanding achievement in U.S. Schools. Educational Researcher, 35(7), 3-12.

Leat, D., Lofthouse, R., \& Reid, A. (2014). Teachers' views: Perspectives on research engagement. Paper \#7 commissioned for the BERA-RSA inquiry The role of research in teacher education: Reviewing the evidence interim report, London. http://www.bera.ac.uk/wp-content/uploads/2013/12/BERAPaper-7-Teachers-Views-Perspectives-on-research-engagement.pdf.

Lieberman, A., \& Miller, L. (Eds.). (2008). Teachers in professional communities: Improving teaching and learning. New York: Teachers College Press.

Lingard, B. (2009). Testing times: The need for new intelligent accountabilities for schooling. Brisbane: Queensland Teachers' Union: http://www.qtu.asn.au/files/9113/2780/3358/29-01-2012_1315_170. pdf.

Lingard, B., Hayes, D., Mills, M., \& Christie, P. (Eds.). (2003). Leading learning. Maidenhead: Open University Press.

Lingard, B., \& Renshaw, P. (2010). Teaching as a research-informed profession. In A. Campbell \& S. Groundwater-Smith (Eds.), Connecting inquiry and professional learning in education: International perspectives and practical solutions (Chapter 3). London: Routledge.

Lupton, R. (2004). Understanding local contexts for schooling and their implications for school processes and quality. British Educational Research Association newsletter. Research Intelligence, 89, 21-26.

Lupton, R. (2006). Schools in disadvantaged areas: Low attainment and a contextualised policy response. In H. Lauder, P. Brown, J. Dillabough, \& A. H. Halsey (Eds.), Education, globalisation and social change (Chapter 45) (pp. 654-672). Oxford: Oxford University Press.

MacBeath, J., Gray, J., Cullen, J., Frost, D., Steward, S., \& Swaffield, S. (2007). Schools on the edge responding to challenging circumstances. London: Paul Chapman Publishing.

Menter, I. (2013). Educational research-What's to be done? Presidential Address, Annual conference of the British Educational Research Association (BERA), Brighton, 3-5 September.

Menter, I., Elliot, D., Hulme, M., Lewin, J., \& Lowden, K. (2011). A guide to practitioner research in education. London: Sage.

Mercier, W. (1909). An experiment in the teaching of history. The Historical Association, Leaflet No. 17. Milner, R. H. (2013). Rethinking achievement gap talk in urban education. Urban Education, 48(1), 3-8.

Moll, L., Amanti, C., Neff, D., \& Gonzalez, N. (1992). Funds of knowledge for teaching: Using a qualitative approach to connect homes and classrooms. Theory into Practice, 31(2), 132-141. 
Mortimore, P., \& Whitty, G. (2000). Can school improvement overcome the effects of disadvantage?. London: University of London.

Munns, G., Sawyer, W., \& Cole, B. (2013). Exemplary teachers of students in poverty. London: Routledge.

Newmann, F. M., \& Associates (1996). Authentic achievement: Restructuring schools for intellectual quality. San Fancisco: Jossey Bass.

Ofsted. (2013). 'Unseen children: Access and achievement 20 years on' evidence report. http://www. ofsted.gov.uk/resources/unseen-children-access-and-achievement-20-years.

Ozga, J., \& Lingard, B. (2007). Globalisation, education policy and pollitics. In B. Lingard \& J. Ozga (Eds.), The Routledge falmer reader in education policy and politics. London: Routledge.

Park, J. (2013). Detoxifying school accountability. The case for multi-perspective inspection. London: Demos. http://www.demos.co.uk/files/Detoxifying_School_Accountability_-_web.pdf?1367602207.

Pollard, A., \& Oancea, A. (2010). Unlocking learning? Towards evidence-informed policy and practice in education. Final report of the UK strategic forum for research in education. London: SFRE. Retrieved July 17, 2011, from http://www.sfre.ac.uk/wp-content/uploads/2008/05/final-report.pdf.

Sahlberg, P. (2010). Finnish Lessons. What can the world learn from educational change in Finland?. New York: Teachers College Press.

Sahlberg, P. (2014). Facts, true facts and research in improving education systems. Inaugural Annual Lecture, British Educational Research Association (BERA), London, 21 May.

Sahlberg, P., Furlong, J., \& Munn, P. (2012). Report of the international review panel on the structure of initial teacher education provision in Ireland conducted on behalf of the Department of Education and Skills, July.

Smyth, J., \& Wrigley, T. (2013). Living on the edge. Rethinking poverty, class and schooling. New York: Peter Lang.

Somekh, B., \& Lewin, C. (2007). Research methods in the social sciences. London: Sage.

Tan, J. (2013). RAISEonline, half-truths and other fictions about attainment gaps. In L. Beckett (Ed.), Teacher education through active engagement: Raising the professional voice (Chapter 2). London: Routledge Research in Education Policy and Politics Series.

Thrupp, M. (1999). Schools making a difference. Let's be realistic! Maidenhead: Open University Press. Thrupp, M. (2009). School improvement. An unofficial approach. London: Continuum.

Wilkinson, R., \& Pickett, K. (2010). The spirit level. Why More equal societies almost always do better. London: Allen Lane. 